\title{
Distribution of carotene and vitamin $A$ in liver, pancreas and body fat of Ghanaians
}

\author{
By J. MAUD DAGADU \\ National Institute of Health and Medical Research \\ P.O. Box 2848, Accra, Ghana \\ (Received ${ }_{13}$ October 1966-Accepted 30 fanuary 1967)
}

\begin{abstract}
1. The carotene and vitamin A levels of liver, pancreas and body fat were determined in seventeen Ghanaians coming from areas where carotene-rich foods were freely available.

2. The liver was confirmed as the main storehouse of vitamin $A$, and vitamin $A$ values for it were exceptionally high. Values for the other tissues were not higher than average.

3. In the study the carotene and vitamin A concentrations in the liver were higher in the females than in the males.

4. Under the conditions of high intake of carotene-rich foods, carotene was found to be distributed more evenly in various tissues than vitamin $\mathrm{A}$.
\end{abstract}

Previous papers have reported the carotene and vitamin A levels in serum, liver, and pancreas of Ghanaians (Dagadu, I963, I965; Dagadu \& Gillman, I963). The levels of carotene and vitamin A were shown to be high in areas where palm oil and carotene-rich fruits and vegetables are consumed in large quantities. Most of the tissues analysed were taken from different groups of subjects at various times in different places. In the study now presented emphasis has been placed on the distribution of carotene and vitamin $\mathrm{A}$ in various tissues taken from the same subject at the same time.

\section{EXPERIMENTAL}

The subjects, who had died at the Korle Bu Hospital, Accra ('a carotene-rich' area; Dagadu, I963) and been brought to the mortuary for autopsy, ranged in age from 5 months to 75 years. There were nine females and eight males. Specimens from each of the seventeen subjects were taken from the liver, the pancreas and the body fat. In most Ghanaian subjects the pancreas and body fat are highly pigmented. Carotene and vitamin $A$ levels were determined in each of the samples by the methods recommended by Glick (I957).

\section{RESULTS}

The carotene and vitamin A concentrations of the various samples from the individual subjects are arranged according to age in Table $\mathrm{I}$. The cause of death and sex of the patients are also shown.

Carotene. Carotene concentration in the livers ranged from 380 to $15000 \mu \mathrm{g} / \mathrm{ro0} \mathrm{g}$, the lowest values being for infants. The mean for liver carotene for the whole group was $5900 \mu \mathrm{g} / \mathrm{I} 00 \mathrm{~g}$; this is lower than the mean of $9200 \mu \mathrm{g} / \mathrm{I} 00 \mathrm{~g}$ previously reported from our laboratories (Dagadu \& Gillman, I963), but is almost twenty times the value reported for accident victims by Berger (1954). In the samples of pancreas, carotene 


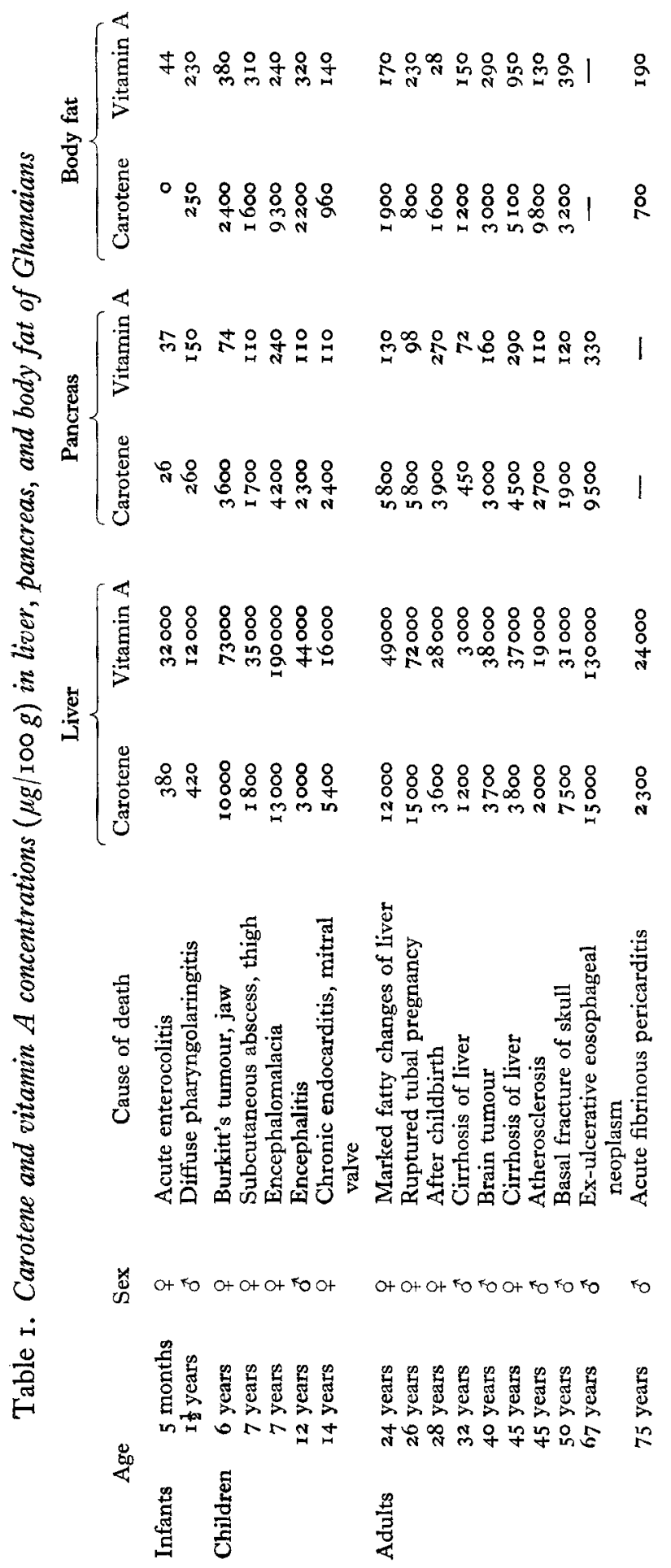


content ranged from 26 to $9500 \mu \mathrm{g} / \mathrm{lo0} \mathrm{g}$, the mean being $3200 \mu \mathrm{g}$. This is similar to the mean reported for samples of highly pigmented pancreas from subjects in Accra (Dagadu, 1964). The carotene levels of the body fat varied from zero in the pale sample obtained from the 5 -month-old baby to a high value of $9800 \mu \mathrm{g} / \mathrm{roo} \mathrm{g}$ in one of the highly coloured samples of fat from the adults. The mean value for the whole group was $2800 \mu \mathrm{g} / \mathrm{IOO} \mathrm{g}$, this being about four to five times the values obtained by Peirce (1954) for highly pigmented specimens of human fat.

Vitamin A. Vitamin A concentration in the liver samples varied from 3000 to a high value of $190000 \mu \mathrm{g} / 100 \mathrm{~g}$. The mean was $49000 \mu \mathrm{g} / \mathrm{I} 00 \mathrm{~g}$, which is similar to a previously reported high mean value (Dagadu \& Gillman, 1963). It is, however, higher than that reported by Smith \& Malthus (1962), twice as high as values reported in Bantus by Leonard (1964), and from about two to twenty times the values reported by various workers as reviewed and tabulated by Smith \& Malthus (1962). In the samples of pancreas analysed vitamin A content ranged from 37 to $33 \circ \mu \mathrm{g} / \mathrm{roo} \mathrm{g}$, with a mean of $150 \mu \mathrm{g} / \mathrm{100} \mathrm{g}$; this mean was lower than the value obtained previously for samples of highly pigmented pancreas (Dagadu, I964). For the samples of body fat, vitamin A levels ranged from 28 to $95^{\circ} \mu \mathrm{g} / \mathrm{roo} \mathrm{g}$, with a mean of $260 \mu \mathrm{g} / \mathrm{roo} \mathrm{g}$; this mean was higher than the value reported by Moore (1957), but similar to the values observed by Peirce (1954) for two samples of highly coloured body fat.

\section{DISCUSSION}

In agreement with Moore (I957), we found that liver contains much larger amounts of vitamin A than do other tissues. Except in one or two subjects, the vitamin A content of the other tissues was under $\mathbf{I} \%$ of that of the liver. It can therefore be said that when large amounts of carotene-rich foods, mainly palm oil, are eaten, the liver still acts as the main storehouse of vitamin $A$ and accumulates large amounts of the vitamin. Age was found to have no effect on the amount of vitamin A stored in the liver. This observation has been reported by other workers (Cleland, 1954; Krause \& Sanders, 1956; Moore, 1957). The vitamin A content of the other tissues did not vary with the sex of the subject, but the mean liver vitamin A content for the females was higher $(59000 \mu \mathrm{g} / \mathrm{ro0} \mathrm{g})$ than for the males $(37000 \mu \mathrm{g} / \mathrm{ro0} \mathrm{g})$. This is contrary to observations by Cleland (1954). The number of subjects was not large enough to enable grouping with respect to vitamin A levels and cause of death.

Moore (1957) reported that carotenoids tend to be more evenly distributed in the body than vitamin A. The same was observed in this study. Although the mean values for the content of carotene samples of pancreas and body fat appeared to be $50 \%$ of those for the liver, in individual instances carotene contents were not always lower in these tissues than in the liver. In certain subjects, the values for the pancreas or body fat, or for both, were higher than the values for the liver (Table I). Apart from low levels of carotene observed in infancy, age had no effect on the accumulation of carotene in the tissues; in females, again, mean liver carotene contents were higher $(7000 \mu \mathrm{g} / \mathrm{ro0} \mathrm{g})$ than in the males $(4000 \mu \mathrm{g} / \mathrm{ro0} \mathrm{g})$; in the other tissues carotene contents did not vary according to the sex of the subject. 
I wish to thank Dr J. Kovi (Pathologist) for providing me with the specimens and also for diagnosing the causes of death, and Professor J. Gillman for his advice and encouragement during this work.

\section{REFERENCES}

Berger, S. (1954). Roczn. Pañst. Zakl. Hig. 5, 207. Quoted in Nutr. Abstr. Rev. 1955, $25,225$. Cleland, J. B. (1954). Med. F. Aust. i, 588. Quoted in Nutr. Abstr. Rev. 1956, 26, 773.

Dagadu, J. M. (1963). Ghana med. Y. 2, no. 4, p. 153 .

Dagadu, J. M. (1964). Ghana med. F. 3, no. 2, p. 89 .

Dagadu, J. M. (1965). Ghana med. F. 4, no. 3, p. I2I.

Dagadu, J. M. \& Gillman, J. (r963). Lancet i, 53 x.

Glick, D. (1957). Methods of Biochemical Analysis. Vol. 4. New York: Interscience Publishers Inc. Krause, R. F. \& Sanders, P. L. (1956). Am. F. clin. Nutr. 4, 68.

Leonard, P. J. (1964). E. Afr. med. F. 41, I33. Quoted in Nutr. Abstr. Rev. 1965, 35, 1087.

Moore, T. (1957). Vitamin A. London: Elsevier Publishing Company.

Peirce, A. W. (1954). Med. F. Aust. i, 589. Quoted in Nutr. Abstr. Rev. 1956, 26, 773.

Smith, B. M. \& Malthus, E. M. (1962). Br. F. Nutr. 16, 2 13. 